Available online on 15.02.2020 at http://jddtonline.info
Open Access to Pharmacentical and Medical Research
unrestricted non-commercial use, provided the original work is properly cited

Open $\odot$ Access

Research Article

\title{
A Comparative Study of Analgesic, Antidiarrhoeal and Antimicrobial Activities of Methanol and Acetone Extracts of Fruits Peels of Limonia acidissima L. (Rutaceae)
}

\author{
Fahadul Islam, A.K. Azad*, Md. Faysal, Md. A.K. Azad, Saiful Islam, Md. Al Amin, Nahida Sultana, \\ Farhana Yeasmen Dola, Md. Mominur Rahman, Md. Zamshed Alam Begh \\ Department of pharmacy, Daffodil International University, Dhaka, Bangladesh
}

\begin{abstract}
Objectives: Present study was designed to evaluate Analgesic, Antidiarrhoeal and Antimicrobial activities of methanol and acetone extracts of fruit peels of Limonia acidissima L. by different methods.

Method: The analgesic activity of the samples was studied using acetic acid- induced writhing model in mice. Castor oil-induced antidiarrheal activity was observed by Thomas method and antimicrobial activity was monitored by disc diffusion method.

Results: Limonia acidissima L. inhibited $60.53 \%$ and $59.65 \%$ writhing of methanol as well as acetone fruit peels extracts, respectively, compared to standard drug Diclofenac Na inhibited $78.07 \%$ writhing. At higher dose (500 mg/kg) of the methanol and acetone fruit peels extracts, significant inhibition 47.13 and $44.83 \%$ of characteristic diarrhoeal feces was observed, respectively, as well as at lower dose (250 $\mathrm{mg} / \mathrm{kg}$ ) of the both extracts, inhibition 34.45 and35.63\%. Mention able on average $12 \mathrm{~mm}$ zone of inhibition was observed of both extract at $250 \mu \mathrm{g} / \mathrm{disc}$ and $500 \mu \mathrm{g} /$ disc compare to zone of inhibition $36 \mathrm{~mm}$ of ciprofloxacin at $50 \mu \mathrm{g} / \mathrm{disc}$.
\end{abstract}

Conclusion: From the above results, it will be very much possible source for an isolating lead compound for curing the numerous disorders.

Keywords: Limonia acidissima L. Fruit peels, Diclofenac sodium, Loperamide, Ciprofloxacin.

Article Info: Received 20 Nov 2019; Review Completed 16 Jan 2020; $\quad$ Accepted 23 Jan 2020; Available online 15 Feb 2020

Cite this article as:

Islam F, Azad AK, Faysal M, Azad MAK, Islam S, Amin MA, Sultana N, Dola FY, Rahman MM, Md. Begh ZA, A Comparative Study of Analgesic, Antidiarrhoeal and Antimicrobial Activities of Methanol and Acetone Extracts of Fruits Peels of Limonia acidissima L. (Rutaceae), Journal of Drug Delivery and Therapeutics. 2020; 10(1-s):62-65 http: //dx.doi.org/10.22270/jddt.v10i1-s.3882

*Address for Correspondence:

A.K. Azad, Department of pharmacy, Daffodil International University, Dhaka, Bangladesh

\section{INTRODUCTION}

The use of medicinal plants as a source for abatement from ailment can be marked back over five millenary to written documents of the early civility in China, India and the Near east. From that time it is used abundantly for the curing puppose of the mankind. ${ }^{1-2}$.

Limonia acidissima $\mathrm{L}$. is the family of Rutaceae (Citrus family) which belongs to the monotypic genus Limonia, confined to India, Pakistan, Sri Lanka and Southeast Asia ${ }^{3}$. It is also known as woodapple, elephant-apple, curd fruit, kath bel as well askaitha. This plant parts are used as a medicine for the treatment of several disorders ${ }^{4}$. Wood apple is an erect, slow-growing tree with a few upward-reaching branches bending outward near the summit. The bark is ridged, fissured and scaly. The deciduous, alternate leaves, 3 to 5 in long, dark-green, leathery, often minutely toothed. Yellowish green flowers, tinged with red, $1 / 2$ in across, are borne in small, loose, terminal or lateral panicles.The tree is mostly known for its hard woody fruit, size of a tennis ball, round to oval in shape. The pulp is brown, mealy, odorous, resinous, astringent, acid or sweetish. ${ }^{5}$. Especially it is used for treating indigestion, flatulence, diarrhoea, dysentery and haemorrhoids. The bark is chewed with that of Barringtonia and applied on venomous wounds 6 .

NSAIDs (Non-steroidal anti-inflammatory drugs) are widely used as analgesic drugs which are used as relieving pain as well as inflammation. Analgesic are the drugs which relieves pain selectively without blocking the conduction of nerve impulses, noticeably changing sensory sensation, whether touching consciousness 7,8. Analgesics minimize the levels of chemical mediators (prostaglandins) produced during inflammation, relieving symptoms of pain, swelling as well as redness. They inhibit the enzyme cyclo-oxygenase (COX 2) that is integral in the synthesis of prostaglandins. Through infection, the effect of prostaglandins on the 
hypothalamus resulting increasing body temperature. They are not only inhibiting local prostaglandin production, but also whole the body ${ }^{9}$. Diarrhoeal disease has long been perceived as a leading cause of morbidity and mortality; paramount cause of sickness as well as death among young children especially in developing countries ${ }^{10}$. Diarrhoea is distinguished by increased frequency of bowel movement, watery stool as well as abdominal pain. Miscellaneous national and international organizations are trying to control this disease but the rate of incidence is still high, approximately 7.1 million per year. A lot of synthetic chemicals are available for the treatment of diarrhoea but they have some major side effects 11,12 .

Medicinal plants represent a rich origin of antimicrobial agents. Plants are used medicinally in different countries as well as are a source of many potent and powerful drugs 13 . Antimicrobial compounds that play an essential role in the natural advocacy of all kinds of living organisms 14 . The antimicrobial compounds from natural sources may be inhibited bacteria by a different mechanism than the presently used antibiotics and may have clinical value in treatment of resistant microbial strains 15 .

Development of newer and more powerful drugs with lesser side effects, plants could be the best choice.

\section{MATERIALS AND METHODS:}

\section{Chemicals and reagents}

Diclofenac sodium, loperamide, ciprofloxacin, acetic acid and castor oil were used.

\section{Plant Materials}

The peels parts of the fruit of Limonia acidissima L. were collected from near Jahangir Nagar University fields, Dhaka, Bangladesh. The identification of the plant material was confirmed by the experts of Bangladesh National Herbarium, Mirpur, Dhaka and also by the authorities of Botanical Garden, Mirpur, Dhaka.

\section{Drying and grinding}

The collected fruit peels were separated from undesirable materials. Then these were dried in for one week in the sunlight and these were cutting into small pieces. The fruit peels were converted into coarse powder by using a suitable grinder. The powder was stored in an airtight container and kept in a cool, dark and dry place until analysis commenced.

\section{Preparation of methanol and acetone extract}

At first, two clean flat flat-bottomed glass containers was taken and added about 400 and $450 \mathrm{gm}$ of powdered sample into the container, respectively. Then $1500 \mathrm{ml}$ of $90 \%$ methanol and $1800 \mathrm{ml}$ acetone were added into the two containers as well as soaked the powder into the methanol and acetone, respectively. Afterwards, containers were sealed with their contents and kept for a period of 10 days accompanying occasional shaking and stirring. After that, the coarse parts of the fruits were separated from the mixture by using white cotton. Then the liquid portion was also filtered three times with the help of white cotton. Then again, these were filtered through whatman filter paper. Then the filtrate was kept in Rotary evaporator machine which separates solvent and desirable crude extracts was obtained.

\section{Experimental animals}

Swice albino mice (22-25g) were purchased from Jahangir Nagar University, Dhaka, Bangladesh and their ages five to six weeks and were housed in animals cages under standard environmental conditions $\left(22-25^{\circ} \mathrm{C}\right.$, humidity $60-70 \%, 12 \mathrm{hr}$ light: $12 \mathrm{hr}$ dark cycle). The mice were feed with standard pellet diet taken from, Jahangirnagar University, Dhaka. The animals used in this study were cared in accordance with the guidelines on animal experimentation of our institute.

\section{Test Microorganisms}

Five pathogenic bacterial strains were used to evaluate Antimicrobial activity. Three of them were Gram negative (Klebsiella Oxytoca, Vibrio metschnikovii, Escherichia coli) and two was gram positive (Bacillus subtilis, Staphylococcus aureus). All of the bacterial strains were collected from Microbiology Lab of Department of Pharmacy, Dhaka University, Dhaka, Bangladesh.

\section{Analgesic activity}

For analgesic test all mice were divided into six groups. Each group comprises of 4 mice. Control group (received $0.5 \%$ methyl cellulose, per oral), Standard Group (received Diclofenac-Na10mg/ kg intraperitoneally), group III and IV were treated with methanolic fruit peels extracts of Limonia acidissima $\mathrm{L}$. at the doses of 250 and $500 \mathrm{mg}$ per $\mathrm{kg}$ of body weight, respectively and), group V and VI were treated with acitonic fruit peels extracts of Limonia acidissima $L$. at the doses of 250 and $500 \mathrm{mg}$ per kg of body weight, respectively. The analgesic activity of the samples was studied using acetic acid- induced writhing model in mice. Test samples and vehicle were administered orally 30 mins before intraperitoneal administration $10 \mathrm{ml} / \mathrm{kg}$ of $0.7 \%$ acetic acid but Diclofenac-Na was administered intraperitoneally 15 minutes before the acetic acid injection, the mice were observed for specific contraction of body referred to as "writhing" for the next 10minutes [16]. Percentageprotection of acetic acid induced writhing was calculated by the formula. Percentage protection $=(\mathrm{Wc}-$ $\mathrm{Wt}$ )/Wc x100; Where, wc is the mean values of control group and $\mathrm{Wt}$ is the mean values of treated group.

\section{Castor oil-induced diarrhoea}

24 mice were allowed to fast for $18 \mathrm{~h}$ and divided into six groups of four animals each. All groups received castor oil at a dose of $1 \mathrm{ml} /$ animal orally (p.o.). $30 \mathrm{~min}$ after castor oil administration, group I (control group) received vehicle (1\% CMC in distilled water), Group III and Group IV orally received the methanol extract at $250 \mathrm{mg} / \mathrm{kg}$ and $500 \mathrm{mg} / \mathrm{kg}$ doses, respectively and ), Group V and Group VI orally received the acitone extract at $250 \mathrm{mg} / \mathrm{kg}$ and $500 \mathrm{mg} / \mathrm{kg}$ doses, respectively. Group II received the reference drug loperamide (3 mg/kg p.o.). Then the animals were placed separately in cages with filter papers underneath, which was changed every hour. The severity of diarrhoea was assessed each hour for $4 \mathrm{~h}$ and the characteristic diarrhoeal droppings were recorded ${ }^{17}$.

\section{Test of antimicrobial activity by disc diffusion method}

In this method-measured amount of the test samples are dissolved in definite volumes of solvent to give solutions of known concentration $(\mu \mathrm{g} / \mathrm{ml})$. Then sterile materiel filter paper discs are impregnated with known amount of test substances using micropipette and dried. Standard antibiotic discs and discs on which the solvent used to dissolve the samples is adsorbed and dried are used as positive and negative control, respectively. These discs are then placed in petri dishes (120 $\mathrm{mm}$ in diameter) containing a suitable agar medium seeded with the test organisms using sterile transfer loop for anti-microbial screening. The plates are then kept at $40^{\circ} \mathrm{C}$ for facilitating maximum diffusion. The test material diffuses from the discs to the surrounding medium. The plates are then kept in an incubator $\left(37^{\circ} \mathrm{C}\right)$ for 
12-18 hour to allow the growth of the microorganisms. If the test material has any anti-microbial activity, it will inhibit the growth of microorganism giving a clear, distinct zone called "zone of inhibition". The Antimicrobial activity of the test agent is determined by measuring the diameter of the zone of inhibition in term of millimeter. The experiments are carried out three times and the mean of the reading are recorded 18 .

\section{Statistical Analysis}

The results are presented as Mean \pm SEM. Data were analyzed by one-way ANOVA followed by Dunnet's test and $P$ values $<0.001$ were considered statistically significant.

\section{RESULT AND DISCUSSION}

Table 1 Results of Analgesic effect of Limonia acidissima L. fruit peels of methanol(ME) and acetone(AE) extracts on acetic acidinduced writhing in mice.

\begin{tabular}{|c|c|c|}
\hline Treatment & Writhing counting( Mean \pm SEM) & \% of Inhibition \\
\hline Control & $28.5 \pm 0.77$ & $78.07 \%$ \\
\hline Standard (Diclofenac Na) & $6.25 \pm 0.227^{* * *}$ & $57.89 \%$ \\
\hline ME 250mg & $12 \pm 0.37^{* * *}$ & $60.53 \%$ \\
\hline ME 500mg & $11.25 \pm 0.42^{* * *}$ & $56.14 \%$ \\
\hline AE 250mg & $12.5 \pm 0.77^{* * *}$ & $59.65 \%$ \\
\hline AE 500mg & $11.5 \pm 1.18^{* * *}$ & \\
\hline
\end{tabular}

Values are presented as Mean \pm SEM $(\mathrm{n}=4), \mathrm{P}<0.001$, which is significant compared with the control group (one-way ANOVA followed byDunnett's test). ${ }^{* * *}$ Indicates the significance of the result.

Limonia acidissima L. inhibited $60.53 \%$ and $59.65 \%$ writhing of methanol as well as acitone fruit peels extracts, respectively, compared to standard drug Diclofenac $\mathrm{Na}$ inhibited $78.07 \%$ writhing. Here strong prominent effects were observed with both extracts group $(500 \mathrm{mg} / \mathrm{kg}$ ) and this effect is like that of standard group (Table 1). Pain is not always remediable, however there are various ways to medicate it. There are drug treatments, with along pain relievers ${ }^{19}$. The ability to detect noxious stimuli is essential to an organism's survival and wellbeing. The explanation of molecules as well as cell types which underlie normal (acute) pain sensation is key to understanding the mechanisms basic pain hypersensitivity 20. At present, plentiful pain therapies are either inadequate or dangerous side effects. Chronic pain results not only from the corporal insult but also from a combination of physical, emotional, psychological, as well as social abnormalities 21 .

Table 2: Effect of methanol(ME) and acetone(AE) extracts of the fruit peels of Limonia acidissima L. on castor oil-induced diarrhoea in mice.

\begin{tabular}{|c|c|c|}
\hline Treatment & No. of faecal droppings in 4h (Mean \pm SEM) & \% Inhibition of defaecation \\
\hline Control & $21.75 \pm 1.18$ & 67.82 \\
\hline Standard (Loperamide) & $7.0 \pm 0.37^{* * *}$ & 34.45 \\
\hline ME 250mg & $14.25 \pm 0.77^{* * *}$ & 47.13 \\
\hline ME 500mg & $11.50 \pm 0.86^{* * *}$ & 35.63 \\
\hline AE 250mg & $14.0 \pm 0.97^{* * *}$ & 44.83 \\
\hline AE 500mg & $12.0 \pm 0.37^{* * *}$ & (on \\
\hline
\end{tabular}

Values are presented as Mean \pm SEM ( $\mathrm{n}=4$ ), $\mathrm{P}<0.001$, which is significant compared with the control group (one-way ANOVA followed by Dunnett's test). ${ }^{* * *}$ Indicates the significance of the result.

The extract at the doses of 250 and $500 \mathrm{mg} / \mathrm{kg}$, produced a dose dependent reduce in the number of faecal matters passed by the mice in castor oil-induced diarrhoeal model (Table 2). At higher dose $(500 \mathrm{mg} / \mathrm{kg})$ of the methanol and acetone fruit peels extracts, significant inhibition 47.13 and $44.83 \%$ of characteristic diarrhoeal feces was observed, respectively, as well as at lower dose $(250 \mathrm{mg} / \mathrm{kg})$ of the both extracst, inhibition 34.45 and35.63 \% of diarrhoeal feces was observed, respectively. The active component of castor oil is the ricinoleic acid, which is liberated from the action of lipases on castor oil. The ricinoleic acid produces irritating and inflammatory actions on the intestinal mucosa leading to the release of prostaglandins which stimulates peristaltic activity in the small intestine, leading to changes in the electrolyte permeability of the intestinal mucosa. As a result, delay diarrhoea induced with castor oil 22 . 
Table 3: In vitro Antimicrobial activity of Limonia acidissima L.on methanol(ME) and acetone(AE) fruit peels extracts.

\begin{tabular}{|c|c|c|c|c|c|c|c|}
\hline \multirow[t]{2}{*}{ Bacterial Strains } & \multirow{2}{*}{$\begin{array}{l}\text { Type of } \\
\text { bacteria }\end{array}$} & \multicolumn{6}{|c|}{ Diameter of zone of inhibition } \\
\hline & & Blank & $\begin{array}{l}\text { Ciprofloxacin }(50 \mu \mathrm{g} \\
\text { /disc })\end{array}$ & $\begin{array}{l}\text { ME(500 } \\
\mu \mathrm{g} / \text { disc })\end{array}$ & $\begin{array}{l}\text { ME (250 } \\
\mu \mathrm{g} / \text { disc) }\end{array}$ & $\begin{array}{l}\mathrm{AC}(250 \\
\mu \mathrm{g} / \text { disc })\end{array}$ & $\begin{array}{l}\mathrm{AC}(500 \\
\mu \mathrm{g} / \text { disc })\end{array}$ \\
\hline Klebsiella Oxytoca & $\operatorname{Gram}(-)$ & - & $36 \mathrm{~mm}$ & $12 \mathrm{~mm}$ & $9 \mathrm{~mm}$ & $11 \mathrm{~mm}$ & $7 \mathrm{~mm}$ \\
\hline Vibrio metschnikovii & $\operatorname{Gram}(-)$ & - & $41 \mathrm{~mm}$ & $11 \mathrm{~mm}$ & $16 \mathrm{~mm}$ & $13 \mathrm{~mm}$ & $14 \mathrm{~mm}$ \\
\hline Escherichia coli & $\operatorname{Gram}(-)$ & - & $38 \mathrm{~mm}$ & $15 \mathrm{~mm}$ & $19 \mathrm{~mm}$ & $14 \mathrm{~mm}$ & $17 \mathrm{~mm}$ \\
\hline Bacillus subtilis & $\operatorname{Gram}(+)$ & - & $39 \mathrm{~mm}$ & $14 \mathrm{~mm}$ & $14 \mathrm{~mm}$ & $10 \mathrm{~mm}$ & $16 \mathrm{~mm}$ \\
\hline $\begin{array}{l}\text { Staphylococcus } \\
\text { aureus }\end{array}$ & $\operatorname{Gram}(+)$ & - & $42 \mathrm{~mm}$ & $14 \mathrm{~mm}$ & $17 \mathrm{~mm}$ & $15 \mathrm{~mm}$ & $14 \mathrm{~mm}$ \\
\hline
\end{tabular}

Gram (-):-Gram Negative Bacteria, Gram (+):-Gram Positive Bacteria (-):- No inhibition

The antimicrobial effects of methanol and acetone fruit peels extracts against different test organisms are shown (Table 3). Both extracts were showed moderate inhibitory activity against all of these organisms.

\section{CONCLUSION}

This study on both extracts of Limonia acidissima L. has exhibited that this plant fruit peels has significant analgesic as well as antidiarrhoeal and moderate antimicrobial properties.

Acknowledgements: The authors are grateful to Department of Pharmacy, Daffodil International University to give permission and all sorts of supports to conduct the research.

Compliance with Ethical Standards: The handling and use of animals were in accordance with the National Institute for Health Guide for the Care and Use of Laboratory Animals. Our study was approved by a Research Ethics Committee for animal house of department of pharmacy, Faculty of Allied Health Sciences, Daffodil International University.

Conflict of Interest: The authors declared that they have no conflict of interest.

\section{REFERENCES}

1. Thomson WA, Schultes RE. Medicines from the Earth McGraw-Hill; 1978.

2. Mahesh B, Satish S. Antimicrobial activity of some important medicinal plant against plant and human pathogens. World journal of agricultural sciences. 2008 Nov 4; 4(5):839-43.

3. Wong KC, Wong SN. Volatile constituents of Averrhoa bilimbi L. fruit. Journal of Essential Oil Research. 1995 Nov 1; 7(6):691-3.

4. Khare CP. Indian medicinal plants: an illustrated dictionary. Springer Science \& Business Media; 2008 Apr 22.

5. Efloraofindia. Limonia acidissima. Available from https://sites.google.com/site/efloraofindia/species/m--$\mathrm{z} / \mathrm{r} /$ rutaceae/limonia/limonia-acidissima. Accessed 12 March 2019.

6. Useful tropical plants. Limonia acidissima. Available from http://tropical.theferns.info/viewtropical.php?id=Limonia +ac idissima. Accessed 12 March 2019.

7. Choi EM, Hwang JK. Antiinflammatory, analgesic and antioxidant activities of the fruit of Foeniculum vulgare. Fitoterapia. 2004 Sep 1; 75(6):557-65.

8. ENCYCLOPAEDIA BRITANNICA. Analgesic drug. Available from https://www.britannica.com/science/analgesic. Accessed 12 March 2019.
9. Physiopedia. Pharmacology in Pain Management. Available from https://www.physio-

pedia.com/Pharmacology_in_Pain_Management. Accessed 12 March 2019.

10. Hegde MM, Lakshman K, Girija K, KUMAR BA

Lakshmiprasanna V. Assessment of antidiarrhoeal activity of Desmostachya bipinnata L.(Poaceae) root extracts. Boletín Latinoamericano y del Caribe de Plantas Medicinales y Aromáticas. 2010; 9(4):312-8.

11. Maiti A, Dewanjee S, Mandal SC. In vivo evaluation of antidiarrhoeal activity of the seed of Swietenia macrophylla King (Meliaceae). Tropical journal of pharmaceutical research. 2007; 6(2):711-6.

12. Akter R, Hasan SR, Hossain MM, Jamila M, Chowdhury SS, Mazumder ME, Rahman S. Antidiarrhoeal and antioxidant properties of Curcuma alismatifolia leaves. Australian Journal of Basic and Applied Sciences. 2010 Mar 1; 4(3):450-6.

13. Srivastava JP, Lambert J, Vietmeyer N. Medicinal plants: An expanding role in development. The World Bank; $1996 \mathrm{Apr}$ 30.

14. Rauha JP, Remes S, Heinonen M, Hopia A, Kähkönen M, Kujala T, Pihlaja K, Vuorela H, Vuorela P. Antimicrobial effects of Finnish plant extracts containing flavonoids and other phenolic compounds. International journal of food microbiology. 2000 May 25; 56(1):3-12.

15. Eloff JN. Which extractant should be used for the screening and isolation of antimicrobial components from plants? Journal of ethnopharmacology. $1998 \mathrm{Feb} 1 ; 60(1): 1-8$.

16. Ahmed F, Selim MS, Das AK, Choudhuri MS. Anti-inflammatory and antinociceptive activities of Lippia nodiflora Linn. Die Pharmazie-An International Journal of Pharmaceutical Sciences. 2004 Apr 1; 59(4):329-30.

17. Shoba FG, Thomas M. Study of antidiarrhoeal activity of four medicinal plants in castor-oil induced diarrhoea. Journal of ethnopharmacology. 2001 Jun 1; 76(1):73-6.

18. Wiart C, Mogana S, Khalifah S, Mahan M, Ismail S, Buckle M, Narayana AK, Sulaiman M. Antimicrobial screening of plants used for traditional medicine in the state of Perak, Peninsular Malaysia. fitoterapia. 2004 Jan 1; 75(1):68-73.

19. Medicine Plus. Pain. Available from https://medlineplus.gov/pain.html. Accessed 15 March 2019.

20. Basbaum AI, Bautista DM, Scherrer G, Julius D. Cellular and molecular mechanisms of pain. Cell. 2009 Oct 16; 139(2):26784.

21. PNAS. Mechanisms of Pain. Available from https://www.pnas.org/content/98/21/11845. Accessed 15 March 2019.

22. Kase Y, Saitoh K, Makino B, Hashimoto K, Ishige A, Komatsu Y. Relationship between the antidiarrhoeal effects of HangeShashin-To and its active components. Phytotherapy Research: An International Journal Devoted to Pharmacological and Toxicological Evaluation of Natural Product Derivatives. 1999 Sep; 13(6):468-73. 